\title{
Ideological and Hegemonic Practices in Global and Local EFL Textbooks Written for Turks and Persians
}

\author{
Ömer Gökhan Ulum - Dinçay Köksal* \\ Received: July 4, 2019; received in revised form: August 28, 2019; \\ accepted: August 30, 2019
}

\begin{abstract}
:
Introduction: Studies on the relationship between ideology, hegemony and textbooks in applied linguistics have been incremental in recent decades because emergence of critical theory, critical pedagogy, and critical thinking skills from the 1920s on has led scholars to develop a critical perspective towards EFL (English as a Foreign Language) textbooks taking the elements of ideology and hegemony into consideration. These two terms encompass an innumerable number of elements or compounds ranging from nationalism to religion. The importance of meta-narratives originating from the tenets of modernism or modernization has been downgraded from 1960s on because it has been postulated that the world has entered a new age called postmodernism and post-structuralism that have emphasized the role of individuals and criticized the efforts to reinforce post-colonialism, the effects of which can be seen in EFL textbooks. Therefore, it remains crucial to analyze EFL textbooks taking the main elements of ideology and hegemony into account. The aim of this study is to investigate the ideological and hegemonic practices included in globally and locally written EFL textbooks.
\end{abstract}

Methods: Using a mixed method research design, ideological and hegemonic representations included in EFL textbooks were examined qualitatively through descriptive content analysis technique employed to make valid assumptions by interpreting and coding content of textual materials. For the qualitative data, based on a descriptive research design, textbook analyses, documentary analysis, were conducted. As for the inductive content analysis, both globally and locally EFL textbooks were examined. The themes were extracted with the help of the experts since this study entailed inductive content analysis. Each theme was analyzed and perused by the experts. After a rigorous analysis, each theme was compared, and in the last stage common themes were formed.

\footnotetext{
* Ömer Gökhan Ulum, Mersin University, English Language Teaching Department, Mersin, Turkey; omergokhanulum@gmail.com Dinçay Köksal, Çanakkale Onsekiz Mart University, English Language Teaching Department, Çanakkale, Turkey; koksal.dincay@gmail.com
} 


\section{Acta Educationis Generalis \\ Volume 9, 2019, Issue 3}

Results: The findings of the present study show that ideology and hegemony of inner and expanding circle cultures are dominant in EFL textbooks. While the expanding circle culture is dominant in the locally written EFL textbooks, the inner circle culture is extensively included in the globally written ones. However, outer circle countries are excluded and marginalized. Besides, while specific ideologies such as economy and history were highly included in both globally and locally written textbooks, some of them such as law and gender were weakly detected.

Discussion: This present study showed that locally written textbooks dwell more on expanding circles, whereas globally written textbooks except for national geographic textbooks, to a large extent, mention only inner circle. Correspondingly, Abdullah (2009) scrutinized the textbooks in Malaysia and concluded that their textbooks covered local cultures from expanding circles. A similar finding was detected in various textbooks in Chile also including the local culture instead of the target one (McKay, 2003). In our study, the most dominant ideological component was culture (75.87\% in global textbooks and $77.80 \%$ in local textbooks) whose components contain social norms, traditions, beliefs, social values (Williamson, 2000). Surprisingly, in both locally and globally written textbooks, the ideology of culture was prevalent $(75.87 \%$ in global textbooks and $77.80 \%$ in local textbooks). This component was both implicitly and explicitly presented in the textbooks analyzed in this study.

Limitations: Taking the extent of the study into consideration, specific limitations already subsist in hand. Initially, choosing textbooks for the analysis of the existing ideological and hegemonic practices in the materials is a difficult task; hence, a particular and convenience selection criterion was selected. Additionally, as the scope of the study is constructed on English as a foreign or second language - a lingua franca, the selection was built on textbooks written globally and locally.

Conclusion: In locally written textbooks, multiculturalism and law-related issues were barely mentioned, while few religion, politics and genderrelated issues were directly mentioned. Some topics, although they were very pivotal across the globe, were never mentioned. The topics of poverty, slavery, and racism were by no means focused on in the textbooks. Thus, it can be said that some topics are underrepresented or never represented owing to the fact that these topics might be too risky. As for the ideology of language, this element was emphasized in both global and local textbooks. The element of education was moderately stressed. Another important element is sport that is prevalent in both global and local EFL textbooks.

Key words: culture; hegemony; ideology; EFL textbooks, critical pedagogy. 


\section{Acta Educationis Generalis \\ Volume 9, 2019, Issue 3}

\section{Introduction}

Ideology is quite a complicated term referring to a broad scope of ideas. James and Steger $(2010$, p.12) give a common definition by suggesting that "ideologies are patterned clusters of normatively imbued ideas and concepts, including particular representations of power relations. These conceptual maps help people navigate the complexity of their political universe and carry claims to social truth." Another important concept is hegemony which can be explained as a practice that coerces individuals and social groups to conform to values in a particular society (Gramsci, 1971). It also refers to social power that derives from past experiences and uncritical views. This process might result in conformist and passive subjects in certain societal contexts (Stoddart, 2007). By considering these important terms, studies on the relationship between ideology, hegemony and textbooks in applied linguistics have been incremental in recent decades because emergence of critical theory, critical pedagogy, and critical thinking skills from the 1920s on has led scholars to develop a critical perspective towards EFL (English as a Foreign Language) textbooks taking the elements of ideology and hegemony into consideration. These two terms encompass an innumerable number of elements or compounds ranging from nationalism to religion. The importance of metanarratives originating from the tenets of modernism or modernization has been downgraded from 1960s on because it has been postulated that the world has entered a new age called postmodernism and post-structuralism that have emphasized the role of individuals and criticized the efforts to reinforce post-colonialism, the effects of which can be seen in EFL textbooks. Therefore, it remains crucial to analyze EFL textbooks taking the main elements of ideology and hegemony into account. In line with this idea, Giroux $(1985,2018 a)$ emphasizes that teachers play important roles in transforming societies by developing critical approaches in their school and classroom settings. Their aim should be to produce responsible citizens and maintain democracy. Thus, teachers can behave as transformative agents in their schools and public space. In addition, Giroux (2018a) notes that teachers can contribute to educational reforms by challenging the ideology-based system in their context, although they can find these topics risky. Ordem and Yukselir (2017) stress the fact that teachers need to develop principles of critical pedagogy by implementing the main tenets of democracy to benefit public and learners, which could contribute to transformation in the society. Ordem (2017) also states that participatory approach, a practical application of critical pedagogy, can be used in classroom settings because learners can be actively involved in preparation of curriculum and syllabus. Giroux (2018b) emphasizes that teachers should have intellectual roles by challenging their traditional roles as in the banking system criticized by Freire (2000). Giroux (2018a, 2018b) articulate that this process of being intellectual and transformative is reflective and interpretative. 


\section{Acta Educationis Generalis \\ Volume 9, 2019, Issue 3}

\section{Literature Review: Analysis of Textbooks in Applied Linguistics}

Mirroring the common sense and principles of a community, textbooks stand as practical tools for educational procedures (Apple \& Christian-Smith, 2017; Hinkel, 2014). While portraying an outstanding role in educational fields, specifically in social sciences, textbooks function as the leading transmitters of the curriculum. They are observed in nearly every classroom setting and control what students acquire (Mahadi \& Shahrill, 2014; Van Dijk, 2004; Wachholz \& Mullaly, 2001).

Course materials in EFL have commonly depicted an ideal society and even some representations in these instructional materials can be irritating for some users (Ballena \& Shim, 2018; Gray, 2016). For instance, the mainstream ideologies (Heywood, 2017) referred to in these materials may have an invalidating impact on different cultures, customs, traditions, or beliefs. Concerning their identities, upon not conforming to the discourse in textbooks (Kramsch, 2014), both students and teachers are inclined to duplicate unfavorable stereotypes and thus maintain misinterpreted typical beliefs (Horvat \& Nilsson, 2018; Safari \& Razmjoo, 2016).

When instructors do not examine textbooks closely for the likely hidden agenda, they may unconsciously serve the ideology which possibly keeps learners in a lower position (Gray, 2000; Tajeddin \& Teimournezhad, 2015; Tomlinson, 2012). Language teacher training departments have commonly concentrated on linguistics, language learning, teaching pedagogy, and teaching methodology without dealing with them in their social and political settings (Nowosad \& Karmolińska-Jagodzik, 2014). In lieu of this, language teachers have been unaware of how teaching practices and language acquisition theories have been conjugated with expansive socio-political dominance. Applied linguistics has just begun investigating the effect of ideological forces on language education practices (Pennycook, 2007; Tollefson, 1995).

EFL teachers should obviously know that course materials, particularly textbooks, cannot ever be impartial with regard to their socio-cultural load (Apple \& Christian-Smith, 2017; Curdt Christiansen \& Weninger, 2015; Gray, 2000, 2016; Nault, 2006; Melliti, 2013). That textbooks explicitly or implicitly carry a body of social messages which are ingrained in their constructs is called hidden agenda which constitutes bias in curricula. These messages may denote notions, beliefs, attitudes or philosophy which have an impact on textbooks, and actually on the overall curriculum (Hurst, 2012; Van Dijk, 2004). In other words, education materials such as textbooks cannot be neutral since they often mirror a frame of ideology directly or indirectly (Cunningsworth, 1995; Liu, 2005; Van Dijk, 2004). Having the main part in a classroom setting and regarded as the required material for attaining the learning objectives, textbooks have gained prominence as an instructional tool (Asghar, 2014; Cortez, 2008; Liu, 2005; Van Dijk, 2004). 


\section{Acta Educationis Generalis \\ Volume 9, 2019, Issue 3}

Besides supplying students' learning needs, the content of the textbook may bear compounds of a hidden agenda to bolster the aimed ideologies of a society, and such a feature of a textbook underlines the power of education which a social group may utilize by leading learning tools and consequently minds of individuals (Asghar, 2014; Liu, 2005). The hidden agenda which has been referred to as a closed discourse by Liu (2005) is essential in educational contexts in which textbooks are exploited as a propagating tool for imposing specific ideologies. The intention of such a discourse is not to form a better human but to develop better devotees of a particular agenda.

When textbooks bear closed discourses which are not similar to learners' own context or social existence, learners may confront a sort of ideological shock (Liu, 2005). In a way, textbook content is shaped by hegemonic practices (Darder, 2014) and selective traditions which supply ideological approval of a social class (May, 2015; Phillipson, 2017), that is, textbooks can be employed as a means of propaganda by specific groups of people. For instance, the scope of the global English textbooks as a state-supported project with an ideological agenda focused basically on improving the trade, ascribing EFL textbooks to political views (Phillipson, 2017). Textbooks portray a significant role in societal formation while their hidden curricula produce dominant ideologies of race, class, and gender (Gugová \& Heretik, 2011). Hence, it is essential to implement a detailed analysis of how textbooks deal with this issue (Van Dijk, 2004).

Furthermore, the issue is not solely about what is contained in the textbook as ideology, but what is not contained as well. While textbooks have the potential to emphasize prevailing ideologies, they also have the potential for neglecting or undermining other ideologies by not covering them in the content. Therefore, an intensive evaluation of textbooks is essential in figuring out how textbooks illustrate the English speaking world and if textbook users are a part of this world (Cortez, 2008; Pennycook, 2003; Kmecová, 2018). While maintaining linguistic and ideological data about the target language, textbooks also have the capability of reinforcing or diminishing the learners' investments in the target language (Cortez, 2008). Ideological discourse analysis of language (Fairclough, 2013) is a common scholarly practice in social sciences, and such an analysis may be conducted through close reading or systematic analysis, if ideologies are intentionally or unintentionally expressed through communication (Han, 2015). Yet, not much is known about how exactly ideologies are developed through discourse, or how they rule the text or talk (Johnstone, 2018; Van Dijk, 2015). Although there has been an increase in the number of analysis of textbooks in applied linguistics based on critical approaches that have been developed in sociology, philosophy, linguistics and psychology, the scope of these studies has been limited to certain cultures. In addition, the sub-elements of ideology and hegemony have been often edited, revised or challenged so as to produce a more detailed and comprehensive understanding of these two terms. Besides, few 


\section{Acta Educationis Generalis \\ Volume 9, 2019, Issue 3}

studies have been carried out considering ideology and hegemony together while analyzing textbooks. Although some progress has been experienced in some EFL textbooks, it seems that ideologies and hegemonies of certain cultures still remain dominant. Therefore, it is important to analyze various textbooks from different cultures including globally and locally written EFL textbooks.

\section{Methodology}

For the qualitative data, based on a descriptive research design, textbook analyses (Bajtoš \& Kmecová, 2013), as documentary analysis, were conducted. As for the inductive content analysis, both globally and locally EFL textbooks were examined. The themes were extracted with the help of the experts since this study entailed inductive content analysis. Each theme was analyzed and perused by the experts. After a rigorous analysis, each theme was compared, and in the last stage common themes were formed.

In order to analyze the ideological compounds ingrained in the textbooks, a checklist was designed by the researchers. At the initial stage of developing the ideology compounds, the one-shot question - What are the compounds of ideology? was directed to the experts from the related fields. The experts majored in critical theory and critical pedagogy in EFL settings. In addition, they established significant connections between textbooks, English teachers, learners, ideology and hegemony in their publications.

The ideological compounds given by these experts are as follows: politics, regime, economy, religion, morals, laws, values, political parties, foundations, ethnicity, gender, partialism, reductionism, identity, tasks, goals, norms, intelligence, honesty, solidarity, equality, tolerance, empathy, holistic view, charity, affirmative action, multiculturalism, language, education, culture, history, sport, and health. However, exposing these ideological compounds into Content Validity Index, those above 0.83 I-CVI value were employed in the analysis of cultural compounds. The utilized compounds emerged after the Content Validity Index are as follows: politics, regime, economy, religion, morals, laws, values, political parties, ethnicity, gender, partialism, reductionism, identity, tasks, goals, norms, intelligence, honesty, solidarity, equality, affirmative action, multiculturalism, language, education, culture, history, and sport. Content validity is the point to which an instrument has a proper sample of items for the construct being tested and is a required practice in scale development (Polit \& Beck, 2006). In the analysis, some compounds were evaluated within the same category. For example, political parties and regime compounds were integrated into politics, while morals and honesty were involved in affirmative action. Besides, norms, values, and multi-culturalism were mentioned in culture ideology. The mentioned compounds were the determinant ideological elements taken into consideration during the ideology analysis process. Furthermore, for the hegemonic compounds, a content analysis 


\section{Acta Educationis Generalis \\ Volume 9, 2019, Issue 3}

was conducted in accordance with the three concentric circles of Kachru (1990): inner, outer, and expanding.

Ideological analysis of language is a commonly applied academic practice in the humanities and the social sciences. The assumption of such analyses is that ideologies of writers and speakers may be revealed by systematic analysis when they intentionally or unintentionally signify their ideologies by means of language (Lee, 2017; Van Dijk, 2004). Texts are essential tools for generating ideologies (Shah, Tariq, \& Bilal, 2013); therefore, examining the ideology behind texts may clarify several hidden messages (Johnstone, 2018). Although a very limited number of studies analyzing the ideology in texts are seen in the related field, there seem to be few studies providing a comparative analysis of EFL textbooks. Though EFL texts have commonly expressed an ideal community (Gómez-Rodríguez, 2015), some of the texts can still be irritating for certain individuals. For instance, the dominant ideologies included in textbooks may place an unfavorable impact on the different lifestyles we bear in our classrooms (Lee, 2011, 2017). When learners cannot conform to their identities within the textbook, they are likely to form contradictory stereotypes and consequently maintain misinterpreted typical beliefs. If the instructors do not examine textbooks closely for the likely hidden agenda (Hahl, Niemi, \& Longfor, 2015; Tomlinson, 2012), learners may become collaborators of the power which place them in an inferior position (Canale, 2016; Lara, 2012).

In line with this methodological design, the main purpose of this study is to investigate the ideological and hegemonic practices in globally and locally written EFL textbooks for Turks and Persians. Firstly, it aims to explore whether globally and locally written EFL textbooks contain values, beliefs, norms of native speaker society through the examination of ideological compounds. Secondly, this study attempts to inquire the hegemonic practices in which the source society or state dictates over the learners of the language. Within this framework, the following research questions are put forward:

What are the underlying ideologies and hegemonic practices represented in globally and locally written EFL textbooks?

More specifically;

1. How do globally and locally written EFL textbooks portray the underlying ideologies?

2. How do globally and locally written EFL textbooks portray hegemonic practices?

\section{Data analysis and findings}

\subsection{Ideology and Hegemony in Globally Written EFL Textbooks}

The extent of ideological and hegemonic practices utilized in globally written textbooks is portrayed within this section. The globally written textbooks include 


\section{Acta Educationis Generalis \\ Volume 9, 2019, Issue 3}

Worldlink $1 / 2$ by National Geographic, Speakout Elementary/Pre-intermediate by Pearson, and Touchstone 1/2 by Cambridge University Press.

\subsubsection{Ideology and Hegemony in Worldlink $1 / 2$ by National Geographic}

Table 1

\begin{tabular}{lrr} 
Ideologies Included in Worldlink $1 / 2$ & by National Geogra \\
\hline Items & \multicolumn{1}{c}{$f$} & $\%$ \\
\hline Ideology of Culture & 636 & 72.52 \\
Ideology of Economy & 113 & 12.88 \\
Ideology of Language & 50 & 5.70 \\
Ideology of Education & 38 & 4.33 \\
Ideology of Sport & 22 & 2.51 \\
Ideology of History & 10 & 1.14 \\
Ideology of Gender & 4 & 0.46 \\
Ideology of Solidarity & 3 & 0.34 \\
Ideology of Affirmative Action & 1 & 0.12 \\
Total & 877 & 100.00 \\
\hline
\end{tabular}

One can understand from Table 1 that Ideology of Culture (72.52\%) was detected to supremely outnumber its counterpart ideologies ranging subsequently as Ideology of Economy (12.88\%), Ideology of Language (5.70\%), Ideology of Education (4.33\%), Ideology of Sport (2.51\%), Ideology of History $(1.14 \%)$, Ideology of Gender $(0.46 \%)$, Ideology of Solidarity $(0.34 \%)$, and Ideology of Affirmative Action (0.12\%).

3.1.2 Ideology and Hegemony in Speakout Elementary/Pre-intermediate by Pearson

Table 2

Ideologies Included in Speakout Elementary/Pre-intermediate by Pearson

\begin{tabular}{lrr}
\hline Items & $f$ & $\%$ \\
\hline Ideology of Culture & 922 & 77.61 \\
Ideology of Economy & 103 & 8.67 \\
Ideology of Sport & 32 & 2.69 \\
Ideology of Language & 30 & 2.53 \\
Ideology of History & 21 & 1.77 \\
Ideology of Education & 18 & 1.52 \\
Ideology of Laws & 18 & 1.52 \\
Ideology of Solidarity & 14 & 1.18 \\
\hline
\end{tabular}




\begin{tabular}{lrr}
\hline Ideology of Affirmative Action & 12 & 1.01 \\
Ideology of Politics & 9 & 0.75 \\
Ideology of Gender & 6 & 0.50 \\
Ideology of Religion & 3 & 0.25 \\
Total & 1188 & 100.00 \\
\hline
\end{tabular}

It can be observed from the table that Ideology of Culture (77.61\%) was observed to highly surmount its equivalents ranging subsequently as Ideology of Economy (8.67\%), Ideology of Sport (2.69\%), Ideology of Language (2.53\%), Ideology of History (1.77\%), Ideology of Education (1.52\%), Ideology of Laws $(1.52 \%)$, Ideology of Solidarity (1.18\%), Ideology of Affirmative Action $(1.01 \%)$, Ideology of Politics $(0.75 \%)$, Ideology of Gender $(0.50 \%)$, and Ideology of Religion $(0.25 \%)$.

3.1.3 Ideology and Hegemony in Touchstone $1 / 2$ by Cambridge University Press

Table 3

Ideologies Included in Touchstone 1/2 by Cambridge University Press

\begin{tabular}{lrr}
\hline Items & \multicolumn{1}{c}{$f$} & \multicolumn{1}{c}{$\%$} \\
\hline Ideology of Culture & 675 & 76.88 \\
Ideology of Economy & 78 & 8.89 \\
Ideology of Language & 52 & 5.92 \\
Ideology of Sport & 43 & 4.90 \\
Ideology of History & 11 & 1.25 \\
Ideology of Education & 9 & 1.03 \\
Ideology of Solidarity & 4 & 0.46 \\
Ideology of Affirmative Action & 3 & 0.34 \\
Ideology of Religion & 2 & 0.22 \\
Ideology of Gender & 1 & 0.11 \\
Total & 878 & 100.00 \\
\hline
\end{tabular}

We can easily understand from the table that Ideology of Culture (76.88\%) was observed to highly surmount other ideologies varying as Ideology of Economy (8.89\%), Ideology of Language (5.92\%), Ideology of Sport (4.90\%), Ideology of History $(1.25 \%)$, Ideology of Education (1.03\%), Ideology of Solidarity $(0.46 \%)$, Ideology of Affirmative Action (0.34\%), Ideology of Religion (0.22\%), and Ideology of Gender $(0.11 \%)$. 


\section{Acta Educationis Generalis \\ Volume 9, 2019, Issue 3}

Table 4

\begin{tabular}{llrr}
\multicolumn{3}{l}{ Overall Cultural hegemony in Globally } & \multicolumn{3}{c}{ Written EFL Textbooks } \\
\hline Items & & \multicolumn{1}{c}{$\%$} \\
\hline \multirow{3}{*}{ Culture } & Inner & 1089 & 50.35 \\
& Expanding & 975 & 45.09 \\
Total & Outer & 98 & 4.56 \\
& & 2162 & 100.00 \\
\hline
\end{tabular}

Regarding the overall cultural hegemony in globally written textbooks, it is easily observed that the inner circle cultural compounds $(50.35 \%)$ slightly outnumber the expanding circle group (45.09\%), while both inner and expanding circle groups significantly surpass the outer circle group (4.56\%).

Table 5

Overall Ideologies Included in Globally Written EFL Textbooks

\begin{tabular}{lrr}
\hline Items & \multicolumn{1}{c}{$f$} & \multicolumn{1}{c}{$\%$} \\
\hline Ideology of Culture & 2233 & 75.87 \\
Ideology of Economy & 294 & 9.99 \\
Ideology of Language & 132 & 4.49 \\
Ideology of Sport & 97 & 3.30 \\
Ideology of Education & 65 & 2.21 \\
Ideology of History & 42 & 1.43 \\
Ideology of Solidarity & 21 & 0.71 \\
Ideology of Laws & 18 & 0.61 \\
Ideology of Affirmative Action & 16 & 0.54 \\
Ideology of Gender & 11 & 0.37 \\
Ideology of Politics & 9 & 0.31 \\
Ideology of Religion & 5 & 0.17 \\
Total & 2943 & 100.00 \\
\hline
\end{tabular}

It is simply apparent from the table that Ideology of Culture (75.87\%) was noted to supremely outnumber other ideologies such as Ideology of Economy (9.99\%), Ideology of Language (4.49\%), Ideology of Sport (3.30\%), Ideology of Education (2.21\%), Ideology of History (1.43\%), Ideology of Solidarity $(0.71 \%)$, Ideology of Laws (1.61\%), Ideology of Affirmative Action $(0.54 \%)$, Ideology of Gender (0.37\%), Ideology of Politics $(0.31 \%)$, and Ideology of Religion $(0.17 \%)$. The following figures clarify the first two items represented for the overall ideologies included in globally written EFL textbooks. 


\section{Acta Educationis Generalis \\ Volume 9, 2019, Issue 3}

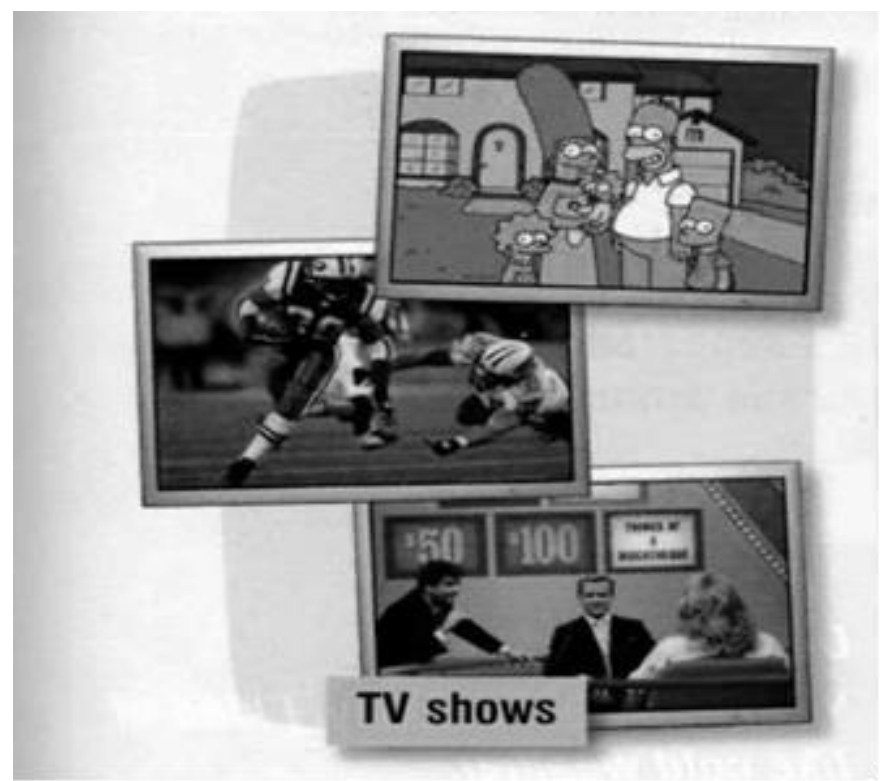

Figure 1. Ideology of Culture in Globally Written EFL Textbooks, Touchstone 2, p. 5 .

Figure 1 simply exemplifies the ideology of culture represented in globally written EFL textbooks. One can easily understand from the figure that The Simpsons Cartoon, American Football, and the TV Show belong to inner circle culture. The following figure also illustrates the ideology of economy included in globally written EFL textbooks.

B Pair work Ask and answer questions about the neighborhood you are in. Use these questions, or think of your own.

Could you recommend a cheap restaurant around here? Is there a place to go skateboarding or biking near here? Can you tell me how to get to the subway or to a bus stop? Could you give me directions to the nearest video arcade?

A Could you recommend a cheap restaurant around here?

B Sure. Try Ann's Diner. When you leave the building, turn lett. Then ...

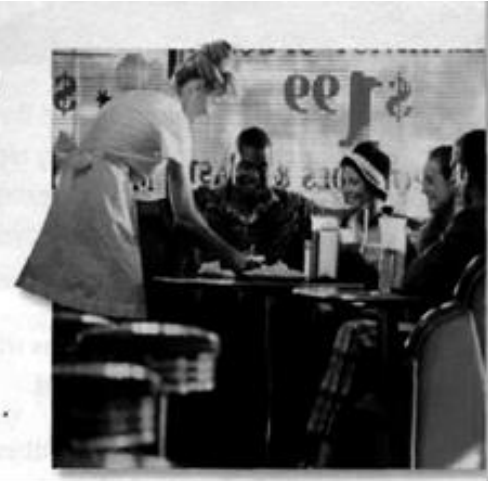

Figure 2. Ideology of Economy in Globally Written EFL Textbooks, Touchstone 2, p. 57. 


\section{Acta Educationis Generalis \\ Volume 9, 2019, Issue 3}

Figure 2 clearly illustrates the ideology of economy included in globally written EFL textbooks. It can be easily figured out from the figure that the money on the wall and the waitress and customers in the restaurant refer to the ideology of economy.

\subsection{Ideology and Hegemony in Locally Written EFL Textbooks}

The extent of ideological and hegemonic practices utilized in locally written EFL textbooks is portrayed within this section. The locally written textbooks include: Progress Preparatory Class; Silver Lining 10; English A1.1; Teenwise; English Course 10; and English A1.2 approved by the Ministry of Turkish National Education, and Prospect 1; Prospect 2; Prospect 3; Vision 1; English Book 2; and English Book 3 approved by the Ministry of Education, Iran.

3.2.1 Ideology and Hegemony in the Locally Written EFL Textbooks Approved by the Turkish Ministry of Education

Table 6

Ideologies Included in the EFL Textbooks Approved by the Ministry of Turkish National Education

\begin{tabular}{lrr}
\hline Items & \multicolumn{1}{c}{$f$} & \multicolumn{1}{c}{$\%$} \\
\hline Ideology of Culture & 1738 & 81.03 \\
Ideology of History & 119 & 5.55 \\
Ideology of Sport & 56 & 2.61 \\
Ideology of Education & 45 & 2.10 \\
Ideology of Economy & 42 & 1.96 \\
Ideology of Language & 38 & 1.77 \\
Ideology of Politics & 31 & 1.45 \\
Ideology of Affirmative Action & 26 & 1.20 \\
Ideology of Solidarity & 17 & 0.79 \\
Ideology of Religion & 15 & 0.70 \\
Ideology of Gender & 10 & 0.47 \\
Ideology of Laws & 8 & 0.37 \\
Total & 2145 & 100.00 \\
\hline
\end{tabular}

As can be observed from the table, Ideology of Culture (81.03\%) was detected to significantly surpass all other ideologies such as Ideology of History (5.55\%), Ideology of Sport (2.61\%), Ideology of Education (2.10\%), Ideology of Economy (1.96\%), Ideology of Language (1.77\%), Ideology of Politics (1.45\%), Ideology of Affirmative Action (1.20\%), Ideology of Solidarity (0.79\%), Ideology of Religion $(0.70 \%)$, Ideology of Gender $(0.47 \%)$, and Ideology of Laws $(0.37 \%)$. 


\section{Acta Educationis Generalis \\ Volume 9, 2019, Issue 3}

3.2.2 Ideology and Hegemony in the Locally Written EFL Textbooks Approved by the Iranian Ministry of Education

Table 7

Ideologies Included in the EFL Textbooks Approved by the Ministry of Education, Iran

\begin{tabular}{lrr}
\hline Items & \multicolumn{1}{c}{$\%$} \\
\hline Ideology of Culture & 768 & 71.78 \\
Ideology of Religion & 88 & 8.22 \\
Ideology of Gender & 43 & 4.02 \\
Ideology of Solidarity & 36 & 3.36 \\
Ideology of Language & 35 & 3.27 \\
Ideology of Economy & 35 & 3.27 \\
Ideology of History & 17 & 1.59 \\
Ideology of Education & 16 & 1.50 \\
Ideology of Affirmative Action & 11 & 1.03 \\
Ideology of Politics & 10 & 0.93 \\
Ideology of Laws & 8 & 0.75 \\
Ideology of Partialism & 3 & 0.28 \\
Total & 1070 & 100.00 \\
\hline
\end{tabular}

It can be easily comprehended from the table that Ideology of Culture (71.78\%) was observed to notably surmount all other ideologies like Ideology of Religion $(8.22 \%)$, Ideology of Gender (4.02\%), Ideology of Solidarity (3.36\%), Ideology of Language (3.27\%), Ideology of Economy (3.27\%), Ideology of History (1.59\%), Ideology of Education (1.50\%), Ideology of Affirmative Action $(1.03 \%)$, Ideology of Politics (0.93\%), Ideology of Laws (0.75\%), and Ideology of Partialism $(0.28 \%)$.

Table 8

Overall Cultural hegemony in Locally Written EFL Textbooks

\begin{tabular}{llrr}
\hline Items & & \multicolumn{1}{c}{$f$} & \multicolumn{1}{c}{$\%$} \\
\hline & Expanding & 1449 & 58.31 \\
Culture & Inner & 938 & 37.75 \\
& Outer & 98 & 3.94 \\
Total & & 2485 & 100.00 \\
\hline
\end{tabular}




\section{Acta Educationis Generalis \\ Volume 9, 2019, Issue 3}

Having a look at the table, we can easily see that the expanding circle group (58.31\%) dominates the overall cultural hegemony in locally written EFL textbooks. Further, while the inner circle $(37.75 \%)$ comes second, the outer circle (3.94\%) comes subsequently third.

Table 9

\begin{tabular}{|c|c|c|}
\hline Items & $f$ & $\%$ \\
\hline Ideology of Culture & 2485 & 77.80 \\
\hline Ideology of History & 136 & 4.26 \\
\hline Ideology of Religion & 103 & 3.22 \\
\hline Ideology of Economy & 77 & 2.41 \\
\hline Ideology of Language & 73 & 2.29 \\
\hline Ideology of Education & 61 & 1.91 \\
\hline Ideology of Sport & 56 & 1.75 \\
\hline Ideology of Solidarity & 53 & 1.66 \\
\hline Ideology of Gender & 53 & 1.66 \\
\hline Ideology of Politics & 41 & 1.28 \\
\hline Ideology of Affirmative Action & 37 & 1.17 \\
\hline Ideology of Laws & 16 & 0.50 \\
\hline Ideology of Partialism & 3 & 0.09 \\
\hline Total & 3194 & 100.00 \\
\hline
\end{tabular}

For the overall ideologies included in locally written EFL textbooks, we can understand from the table that Ideology of Culture (77.80\%) was detected to significantly dominate all other ideologies like Ideology of History (4.26\%), Ideology of Religion (3.22\%), Ideology of Economy (2.41\%), Ideology of Language (2.29\%), Ideology of Education (1.91\%), Ideology of Sport (1.75\%), Ideology of Solidarity (1.66\%), Ideology of Gender (1.66\%), Ideology of Politics (1.28\%), Ideology of Affirmative Action (1.17\%), Ideology of Laws $(0.50 \%)$, and Ideology of Partialism $(0.09 \%)$. The pursuing figures exemplify the first three items given for the overall ideologies included in locally written EFL textbooks. 


\section{Acta Educationis Generalis \\ Volume 9, 2019, Issue 3}

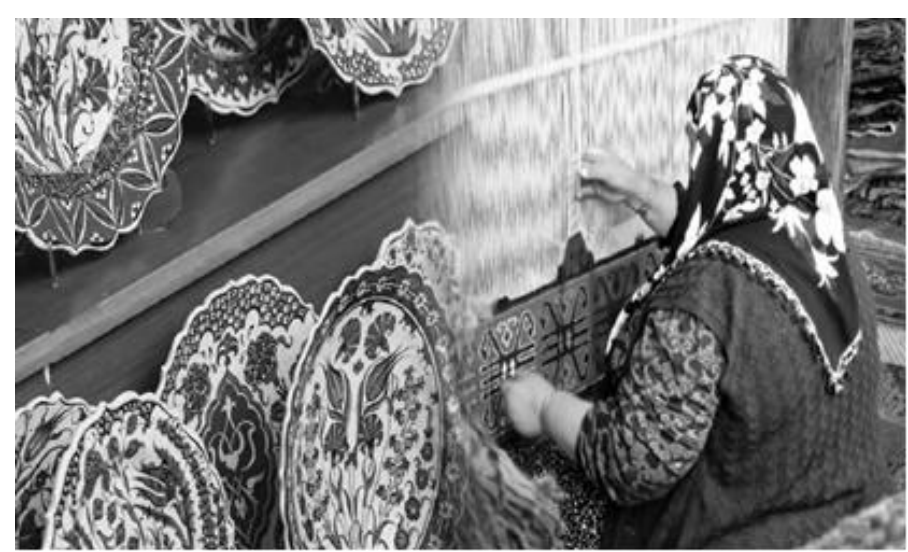

Figure 3. Ideology of Culture in Locally Written EFL Textbooks, English Course 10, p. 27.

The ideology of culture contained in locally written EFL textbooks can be clearly understood from Figure 3. In a similar vein, the woman weaving carpet illustrates the ideology of culture. The following figure exemplifies the ideology of history in locally written EFL textbooks.

E. Read the following text. Whose life story is it? Complete the title with the person's name.

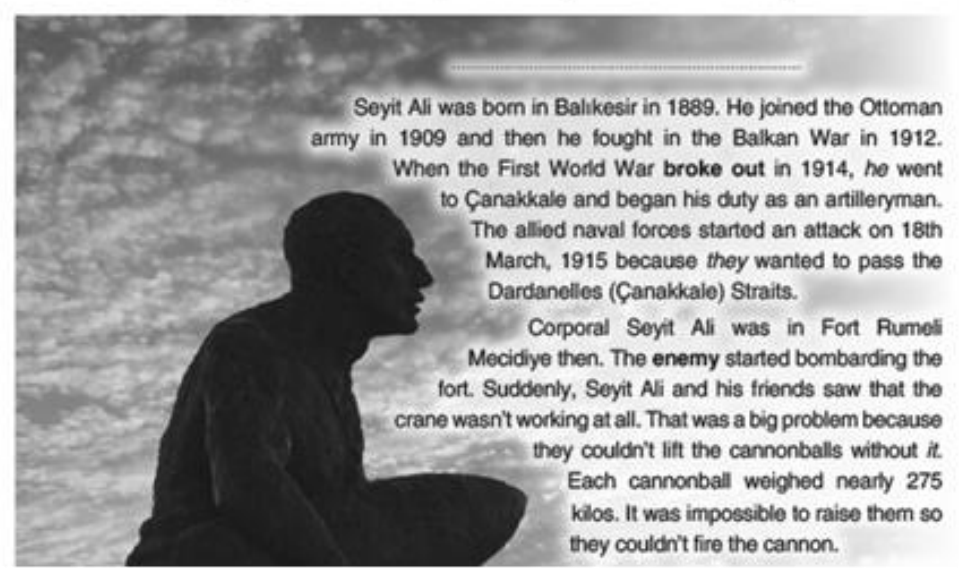

Figure 4. Ideology of History in Locally Written EFL Textbooks, English Course 10, p. 23.

The ideology of history covered in locally written EFL textbooks can be easily comprehended from Figure 4. That's to say, the legendary figure Seyit Ali in Turkish history may be given as an example of ideology of history. Further, the figure below represents the ideology of religion in locally written EFL textbooks. 


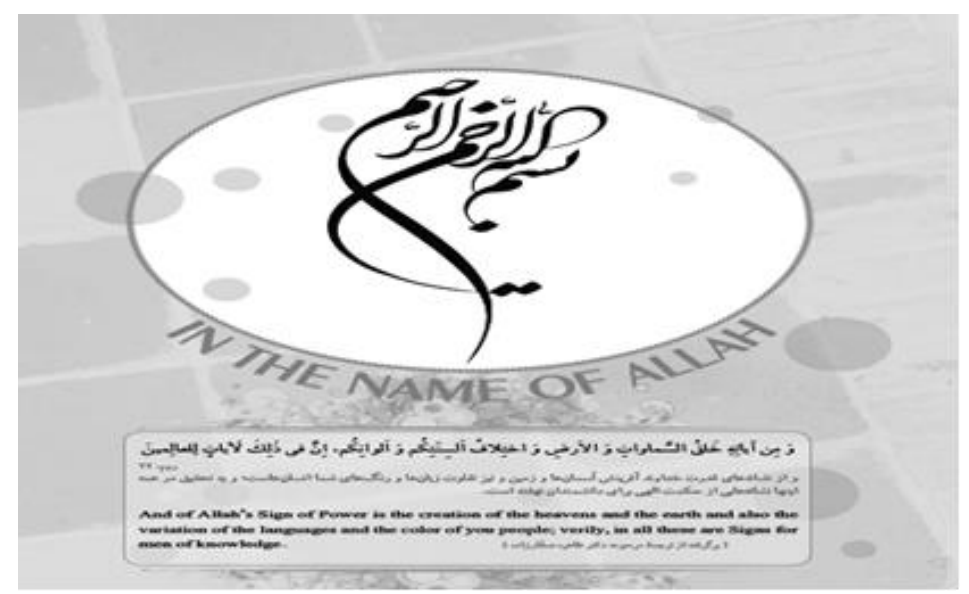

Figure 5. Ideology of Religion in Locally Written EFL Textbooks, Prospect 1, p. 4.

By looking at Figure 5, one can easily detect the ideology of religion included in locally written EFL textbooks. Likewise, the religious text both in Arabic and English represent the ideology of religion.

\section{Discussion}

Globally and locally written EFL textbooks containing the values, beliefs, norms of native speaker society through the examination of ideological compounds have been analyzed. Similarly, Lee (2009) and McKay (2003) emphasize the fact that textbooks are seen as the chief source for teaching language and culture to examine the cultural content of ELT textbooks across the globe. In line with the ideas of Hamiloğlu and Mendi (2010), Lee (2009), and McKay (2003) discovered that four textbooks incorporated components from various cultures, while one concentrated on Anglo-American cultural aspects. This present study showed that locally written textbooks dwell more on expanding circles, whereas globally written textbooks except for national geographic textbooks, to a large extent, mention inner circle. Correspondingly, Abdullah (2009) scrutinized the textbooks in Malaysia and concluded that their textbooks covered local cultures from expanding circles. A similar finding was found in various textbooks in Chile also including the local culture instead of the target one (McKay, 2003). In our study, the most dominant ideological component was culture $(75.87 \%$ in global textbooks and $77.80 \%$ in local textbooks) whose components contain social norms, traditions, beliefs, social values (Williamson, 2000). Surprisingly, in both locally and globally written textbooks, the ideology of culture was prevalent $(75.87 \%$ in global textbooks and $77.80 \%$ in local textbooks). This component was both implicitly and explicitly presented in the textbooks analyzed in this study. 


\section{Acta Educationis Generalis \\ Volume 9, 2019, Issue 3}

In accordance with our study, White (2014) also notes that two textbooks, New Interchange and New Headway used in Iran, are highly ideological and hegemonic since Anglo-American cultures are strongly emphasized through the pictures and materials of these textbooks which portray local lives of these two cultures that ignore other cultural aspects. Cultural imperialism and hegemony can be placidly seen in these books (Roshan, 2014). Stern (1983) maintains that cultural elements can be conceptualized at three levels. The first level includes linguistics, educational, anthropology, sociology, and sociolinguistic theories. The second level incorporates ethnographic or cultural portrayal of the second language. The third level is related to the socio-cultural ground. For Stern, culture, communication and society are synonymous with each other. Similarly, in our study, it was found that three levels related to cultural imperialism and hegemony were seen in globally written textbooks that emphasized the cultural imperialism of inner circle countries, whereas, in locally written textbooks, the cultural imperialism of expanding circle countries was stressed. What is interesting about the findings of this study is that outer circle countries were generally underrepresented, which may show that these countries are still under the effect of the postcolonial idea $(4.56 \%$ in global textbooks and $3.94 \%$ in local textbooks. Speakout and Touchstone textbooks, in particular, refer to inner circle countries whose cultural imperialism is largely emphasized (51.63\% in Speakout and $54.67 \%$ in Touchstone). In National Geographic textbook, expanding and inner circle countries were presented by mentioning their cultural elements (95.76\% in both expanding and inner circles). Similar findings were observed in Greek English language books imposing cultural and dominant ideologies in ELT settings (Fotopoulos, Karra, \& Zagkos, 2017). Similarly, Garcia (2005) focused on 14 first- and second-course ELT textbooks in Spain to analyze international and intercultural aspects. They found that a cross-cultural approach (Osad'an \& Safir, 2014) was not adopted and mentioned in these textbooks through which learners could advance intercultural competence. In our study, Iranian textbooks discarded intercultural competence because they focused more on their own cultures. However, inner circle was underrepresented (15.89\%). However, global textbooks presented intercultural competence implicitly. What is interesting is that the textbooks written by the Ministry of Turkish Education spared a specific chapter for intercultural competence. The representation ratio of the inner circle in the textbooks written by the Ministry of Turkish Education is as high as global textbooks (46.95\%). Further research could incorporate ideology and hegemony of other cultures situated in expanding and outer circles because the dominance of inner circle cultures needs to be challenged critically. In addition, interdisciplinary research by including sociology, social psychology, philosophy and education can be carried out in the future in order to unravel challenging perspectives regarding ideology and hegemony. 


\section{Acta Educationis Generalis \\ Volume 9, 2019, Issue 3}

\section{Conclusion}

The findings of the present study show that ideology and hegemony of inner and expanding circle cultures are dominant in textbooks. Culture was the most prevalent factor in both globally and locally written textbooks. However, this cultural content and perspective is often biased by including their own ideologies implicitly and explicitly. In addition, outer circle countries are excluded and marginalized. In global textbooks, economy is highly emphasized, which may show that they have marketing purposes, whereas locally written textbooks stress the topics of history and religion. Another interesting finding is that religion and politics were barely represented in the globally written EFL textbooks because in Turkey discussion of socio-political issues are perceived as risky. Therefore, few teachers and textbooks focus on these topics. In line with this finding, a critical approach can be adopted in order to emancipate learners and textbooks from fixed ideologies. A similar problem can be applied to countries that are in the expanding circle. Iranian textbooks highlight religion, while Turkish EFL textbooks focus on history because religion and history are dealt with uncritically, which poses no risk for learners and teachers. In Turkey, the teaching of history is never criticized, which reinforces only nationalistic ideas. One cannot develop a critical perspective towards history and religion, which are regarded as taboo topics.

In locally written textbooks, multiculturalism and law-related issues were barely mentioned, while few religion, politics and gender-related issues were directly mentioned. Some topics, although they were very pivotal across the globe, were never mentioned. The topics of poverty, slavery, and racism were by no means focused on in the textbooks. Alhtough critical theory and critical pedagogy have been developed in humanities in recent decades, English language teaching and EFL textbooks tend to refrain from these topics mentioned above. Therefore, poststructuralism has been never prevalent in EFL settings and textbooks. Thus, it can be said that some topics are underrepresented or never represented owing to the fact that these topics might be too risky. As for the ideology of language, this element was emphasized in both global and local textbooks. The element of education was moderately stressed.

It can be interpreted that exclusion of certain topics might be ideological in nature because ideology and hegemony are indispensable parts of language, particularly both local and global textbooks. Thus, we can say that textbooks are never neutral. This problem has been emphasized in the related literature in recent decades. Thus, we can conclude that minds are manipulated and socially constructed. Since these textbooks can be perceived as extensions of the media, it can be said that certain topics are deliberately framed with care by authors of global and local textbooks because even local textbooks and textbook authors might behave in accordance with the socio-political system of their own cultures. Iranian textbooks insistently impose religious ideas on EFL learners by excluding and ignoring western-based ideas. Similarly, Turkish EFL textbooks 


\section{Acta Educationis Generalis \\ Volume 9, 2019, Issue 3}

also stress the importance of history and national identity, which are perceived and constructed as important by the Turkish Ministry of Education, which shows the hegemonic nature of the elites in power. Thus, it can be said that each culture has its own ideological practices that are visibly reflected in EFL textbooks. Therefore, it is not unusual to say that textbooks cannot be neutral. Even global EFL textbooks tend to support their inner circle cultural aspects by ignoring alternative cultures that may be called outer circle owing to the possible effect of post-colonialism.

\section{References}

Abdullah, N. (2009). Cultural Elements in a Malaysian English Language Textbook. Retrieved from http://ddms.usim.edu.my/handle/123456789/713

Apple, M., \& Christian-Smith, L. (Eds.). (2017). The politics of the textbook. New York: Routledge.

Asghar, J. (2014). Thou shalt not think: Editors' voice in an English textbook to propagate vested agendas. Education Research International, 1-8.

Bajtoš, J., \& Kmecová, I. (2013). Analysis evaluating the results from the research of textbooks' didactic efficiency in technical education. Acta Technologica Dubnicae, 3(1), 60-72. https://doi.org/10.1515/atd-2015-0027

Ballena, M. K. R., \& Shim, Y. S. (2018). Representation of social struggles in Korean and Philippine ELT textbooks. 사회언어학, 26(1), 201-228.

Canale, G. (2016). (Re)Searching culture in foreign language textbooks, or the politics of hide and seek. Language, Culture and Curriculum, 29(2), 225243.

Cortez, N. A. (2008). Am I in the book? Imagined communities and language ideologies of English in a global EFL textbook. Retrieved from https://search.proquest.com/docview/304684502?accountid=165093

Cunningsworth, A. (1995). Choosing Your Coursebook. Oxford: Heinemann.

Curdt-Christiansen, X. L., \& Weninger, C. (Eds.). (2015). Language, ideology and education: The politics of textbooks in language education. New York: Routledge.

Darder, A. (2014). Cultural hegemony, language, and the politics of forgetting: Interrogating restrictive language policies. In Affirming Language Diversity in Schools and Society, New York: Routledge.

Fairclough, N. (2013). Critical discourse analysis: The critical study of language. London: Routledge.

Fotopoulos, N., Karra, V., \& Zagkos, C. (2017). Education, ideology and social effigies: Exploring facets from the English course books of the Greek state primary education. International Journal of Education, 9(3), 48-59.

Freire, P. (2000). Pedagogy of the oppressed (Trans. M. Bergman Ramos). New York: Continuum. 


\section{Acta Educationis Generalis \\ Volume 9, 2019, Issue 3}

Garcia, M. D. C. M. (2005). International and intercultural issues in English teaching textbooks: The case of Spain. Intercultural Education, 16(1), 5768.

Gómez-Rodríguez, L. F. (2015). The cultural content in EFL textbooks and what teachers need to do about it. Profile Issues in Teachers Professional Development, 17(2), 167-187.

Gramsci, A. (1971). Selections from the Prison Notebooks of Antonio Gramsci. New York: International Publishers.

Gray, J. (2000). The ELT coursebook as cultural artefact: How teachers censor and adapt. ELT Journal, 54(3), 274-283.

Gray, J. (2016). ELT materials: Claims, critiques and controversies. In The Routledge Handbook of English Language Teaching. New York: Routledge.

Giroux, H. A. (1985). Teachers as transformative intellectuals. Social Education, 49(5), 376-79

Giroux, H. (2018a). Pedagogy and the politics of hope: Theory, culture, and schooling: A critical reader. New York: Routledge.

Giroux, H. A. (2018b). The New Henry Giroux Reader: The Role of the Public Intellectual in a Time of Tyranny. USA: Stylus Publishing, LLC.

Gugová, G. R., \& Heretik, A. (2011). Gender differences in attachment styles using Slovak version of the Experiences in Close Relationships-Revised (ECR-R). Acta Technologica Dubnicae, 1(2), 29-36. https://doi.org/10.1515/atd-2015-0043

Hahl, K., Niemi, P. M., \& Longfor, R. J. (Eds.). (2015). Diversities and interculturality in textbooks: Finland as an example. The UK: Cambridge Scholars Publishing.

Hamiloğlu, K., \& Mendi, B. (2010). A content analysis related to the crosscultural/intercultural elements used in EFL coursebooks. Sino-US English Teaching, 7(1), 16-24.

Han, C. (2015). How to do critical discourse analysis: A multimodal introduction. Australian Journal of Linguistics, 35(4), 415-418.

Heywood, A. (2017). Political ideologies: An introduction. The UK: Palgrave Macmillan.

Hinkel, E. (2014). Culture and pragmatics in language teaching and learning. Teaching English as a second or foreign language, 4, 394-408.

Horvat, A., \& Nilsson, K. (2018). An Analysis of Swedish EFL TextbooksReflections on Cultural Content and English as an International Language. Malmö University Electronic Publishing 1(40). Retrieved from http://muep.mau.se/handle/2043/24908

Hurst, N. R. (2012). The Hidden Curriculum: issues and angst about cultural content in ELT materials. Retrieved from http://web.letras.up.pt/nrhurst/ Hidden\%20Curriculum\%20Article\%20-\%20Valladolid.pdf 


\section{Acta Educationis Generalis \\ Volume 9, 2019, Issue 3}

James, P., \& Steger, M. B. (Eds.). (2010). Globalization and culture: ideologies of globalism. The UK: Sage.

Johnstone, B. (2018). Discourse analysis. The USA: John Wiley \& Sons.

Kachru, B. B. (1990). World Englishes and applied linguistics. World Englishes, 9(1), 3-20.

Kmecová, I. (2018). Efficiency of Teaching Based on the Comparison of Textbooks. Acta Educationis Generalis, 8(1), 50-62. https://doi.org/10.2478/atd-2018-0003

Kramsch, C. (2014). Identity, role and voice in cross-cultural (mis) communication. In Misunderstanding in social life. NewYork: Routledge.

Lara, C. (2012). ELT coursebooks and the elite. TESOL-Spain Convention, 35, $1-20$.

Lee, I. (2009). Situated globalization and racism: An analysis of Korean high school EFL textbooks language and literacy. English Teaching: Practice and Critique, 11(1), 1-14.

Lee, I. (2011). Teaching how to discriminate: Globalization, prejudice, and textbooks. Teacher Education Quarterly, 38(1), 47-63.

Lee, D. (2017). Competing discourses: Perspective and ideology in language. Routledge.

Liu, Y. (2005). Discourse, cultural knowledge and ideology: A critical analysis of Chinese language textbooks. Pedagogy, Culture \& Society, 13(2), 233264.

Mahadi, M. A., \& Shahrill, M. (2014). In pursuit of teachers' views on the use of textbooks in their classroom practice. International Journal of Education, $6(2), 149$.

May, S. (2015). The problem with English(es) and linguistic (in)justice. Addressing the limits of liberal egalitarian accounts of language. Critical Review of International Political and Social Philosophy, 18(2), 131-148.

McKay, S. L. (2003). The cultural basis of teaching English as an international language. TESOL Matters, 13(4), 1-6.

Melliti, M. (2013). Global content in global coursebooks: The way issues of inappropriacy, inclusivity, and connectedness are treated in Headway Intermediate. Sage Open, 3(4), 1-12.

Nault, D. (2006). Going global: Rethinking culture teaching in ELT contexts. Language, Culture and Curriculum, 19(3), 314-328.

Nowosad, I., \& Karmolińska-Jagodzik, E. (2014). Contemporary Education Changes of the System, Research Reports and the Dimensions of Real Social Expectations. Acta Technologica Dubnicae, 4(2), 43-59. https://doi.org/10.1515/atd-2015-0005

Ordem, E. (2017). Participatory Approach in EFL Classes. Electronic Turkish Studies, 12(3), 505-516.

Ordem, E., \& Yükselir, C. (2017). Views of Turkish EFL instructors on critical pedagogy. Electronic Turkish Studies, 12(14), 285-294. 


\section{Acta Educationis Generalis \\ Volume 9, 2019, Issue 3}

Osad'an, R., \& Safir, Y. (2014). A Cross-Cultural Examination of Curriculum and Sexuality Outcomes in Primary School. Acta Technologica Dubnicae, 4(2), 67-72. https://doi.org/10.1515/atd-2015-0007

Pennycook, A. (2007). The myth of English as an international language. Disinventing and reconstituting languages (pp. 90-115). Clevedon: Multilingual Matters LTD.

Pennycook, A. (2003). Beyond Homogeny and Heterogeny: English as a Global and Wordly Language. In The Politics of English as a world language: new horizons in postcolonial cultural studies. New York: Editions Rodopi.

Phillipson, R. (2017). Myths and realities of 'global' English. Language Policy, 16(3), 313-331.

Polit, D. F., \& Beck, C. T. (2006). The content validity index: are you sure you know what's being reported? Critique and recommendations. Research in nursing \& health, 29(5), 489-497.

Roshan, S. (2014). A critical comparative evaluation of English course books in EFL context. Journal of Studies in Education, 4(1), 172-179.

Safari, P., \& Razmjoo, S. A. (2016). An exploration of Iranian EFL teachers' perceptions on the globalization and hegemony of English. Qualitative Research in Education, 5(2), 136-166.

Shah, S. K., Tariq, W., \& Bilal, M. (2013). Ideology in English textbooks: A case study of matric level books in Punjab. Research on Humanities and Social Sciences, 3(11), 113-120.

Stern, H. H. (1983). Fundamental concepts of language teaching: Historical and interdisciplinary perspectives on applied linguistic research. Oxford: Oxford University Press.

Stoddart, M. C. (2007). Ideology, hegemony, discourse: A critical review of theories of knowledge and power. Social Thought \& Research, 191-225.

Tajeddin, Z., \& Teimournezhad, S. (2015). Exploring the hidden agenda in the representation of culture in international and localised ELT textbooks. The Language Learning Journal, 43(2), 180-193.

Tollefson, J. W. (1995). Introduction: Language policy, power, and inequality. Power and inequality in language education (pp. 1-8).

Tomlinson, B. (2012). Materials development for language learning and teaching. Language teaching, 45(2), 143-179.

Van Dijk, T. A. (2004). Racism, discourse and textbooks. In The coverage of immigration in Spanish textbooks. Retrieved from http://www.discursos.org/unpublished\%20articles/Racism,\%20discourse, $\%$ 20textbooks.htm

Van Dijk, T. A. (2015). Critical discourse studies: A sociocognitive approach. Methods of Critical Discourse Studies (pp. 63-74).

Wachholz, S., \& Mullaly, B. (2001). The politics of the textbook: A content analysis of the coverage and treatment of feminist, radical and anti-racist social work scholarship in American introductory social work textbooks 


\section{Acta Educationis Generalis}

Volume 9, 2019, Issue 3

published between 1988 and 1997. Journal of Progressive Human Services, 11(2), 51-76.

White, A. (2014). Evaluation of an ELT course book based on criteria designed by McDonough and Shaw. Retrieved from http://www.birmingham.ac.uk/ Documents/college

Williamson, O. (2000). "The New Institutional Economics: Taking Stock, Looking Ahead”. Journal of Economic Literature, 38(3), 595-613. 